\title{
Suspended Matter and Nutrient Gradients of a Small-Scale River Plume in Sepetiba Bay, SE-Brazil
}

\author{
Raphael Paiva Rodrigues ${ }^{1 *}$, Bastiaan Adriaan Knoppers ${ }^{1}$, Weber Friederichs Landim de \\ Souza $^{2}$ and Elisamara Sabadini Santos ${ }^{1}$ \\ ${ }^{I}$ Departamento de Geoquímica; Universidade Federal Fluminense; 24020-007; Niterói - RJ - Brasil. ${ }^{2}$ Instituto \\ Nacional de Tecnologia; Divisão de Química Analítica; Laboratório de Análises Inorgânicas; 20081-312; Rio de \\ Janeiro - RJ - Brasil
}

\begin{abstract}
Coastal river plumes represent one of the final stages of material transport across the land-sea interface. Most studies, however have focused on the behavior of medium to large sized river plumes of coastal-shelf waters, whereas small sized river plumes acting within estuaries have been neglected. This study addressed the behavior of suspended particulate matter (SPM), dissolved inorganic nutrients (DIN, DIP and DSi) and Chlorophyll a (Chl. a) of a small sized river plume derived from the closely lain São Francisco and Guandú river channels, set in the Sepetiba Bay estuary, SE-Brazil. Two surface water sampling campaigns were conducted, one in January 2003 (humid summer conditions) and the other in June 2003 (dry winter conditions). On both occasions, the plumes dispersed in a SE direction towards the inner portion of the bay. The "wet" event plume was more turbid, nutrient rich and dispersed beyond nearshore waters, whereas the "dry" event plume proliferated as a narrow, less turbid and more nutrient poor film alongshore. Both exhibited a marked degree of patchiness, induced by the differential input of materials from the river sources and resuspension processes from the shallow nearshore bottom. The São Francisco river channel was the main source of freshwater, SPM and nutrients, except for ammonia $\left(\mathrm{NH}_{4}{ }^{+}-\mathrm{N}\right)$ derived from domestic effluents of the Guandu river. The mesohaline portion of the estuarine mixing zone of the plumes behaved as a slight source for SPM, DSi and DIP, due to bottom resuspension processes. N:P molar ratios ranged between 80:1 and 20:1 along the estuarine gradient, being higher in the summer than in the winter event, indicating that DIP was the potential nutrient limiting primary production. Chl. a concentrations increased at the outer premises of the plume, suggesting that the short residence times and turbidity of the plume waters, hampered primary production nearshore, particularly during the summer occasion. The small sized plume lacked the spatial decoupling between the estuarine mixing and turbidity zones, generally observed in larger sized coastal-shelf plumes.
\end{abstract}

Key words: suspended matter, nutrients, estuarine gradients, river plume, Sepetiba Bay, SE-Brazil.

\section{INTRODUCTION}

The transport of matter across the land-sea interface occurs at several stages, all of which are controlled by a variety of physical and biogeochemical processes. River borne materials introduced to estuaries are modified in their concentration, character and fate along the

\footnotetext{
* Author for correspondence: rapha_rodrigues@hotmail.com
} 
estuarine mixing zone, as they react due to the sudden changes of salinity, $\mathrm{pH}$, turbidity, respiration and photosynthesis. A fraction of the particulates and associated chemical elements are retained by the accumulation in sediments and others are bypassed to the coast without reaction (Burton and Liss, 1976; Day et al., 1989; Smith and Atkinson, 1994; Turner and Millward, 2002). Henceforth, materials are dispersed by coastal river plumes, during which they are further diluted by mixing with marine waters and lost from the surface waters by gradual sedimentation to the bottom. Finally, ultra-fine particulates and nonutilized or modified inorganic and organic constituents are exported beyond the plumes to the sea (Wright, 1977; Garvine, 1995; Wright and Nittrouer, 1995).

Coastal river plumes are highly diverse in nature, as their extension, form and dispersal dynamics are controlled by the interaction between the magnitude and pulsation of river flow, the wind, tidal and current regimes, local bathymetry and Coriolis forcing (Wright, 1977; Garvine, 1987 and 1995). Most studies focused on the sediment and nutrient dynamics of coastal-shelf plumes generated by the world's medium to large sized rivers, which transport materials offshore (Garvine, 1995; Wright and Nittrouer, 1995). These, generally exhibit a de-coupling between the estuarine mixing zone, where most particle-water reactions occur, and the dispersal of suspended particulate matter (i.e. turbidity) towards their outer euryhaline premises (Turner and Millward, 2002; Berlinsky et al., 2005; Smoak et al., 2005).

In contrast, however, there is still paucity of information on the dispersal patterns and behavior of materials along the estuarine gradients of smallsized river plumes confined to estuarine systems. This study addresses the behavior of suspended particulate matter, nutrients and chlorophyll a of a small-sized river plume, generated by the main fresh water source of the Sepetiba Bay estuary, SE-Brazil. It compares conditions between a high and a low river discharge event and discusses some of the processes affecting the transfer of land derived materials to the bay, including their potential of fertilization.

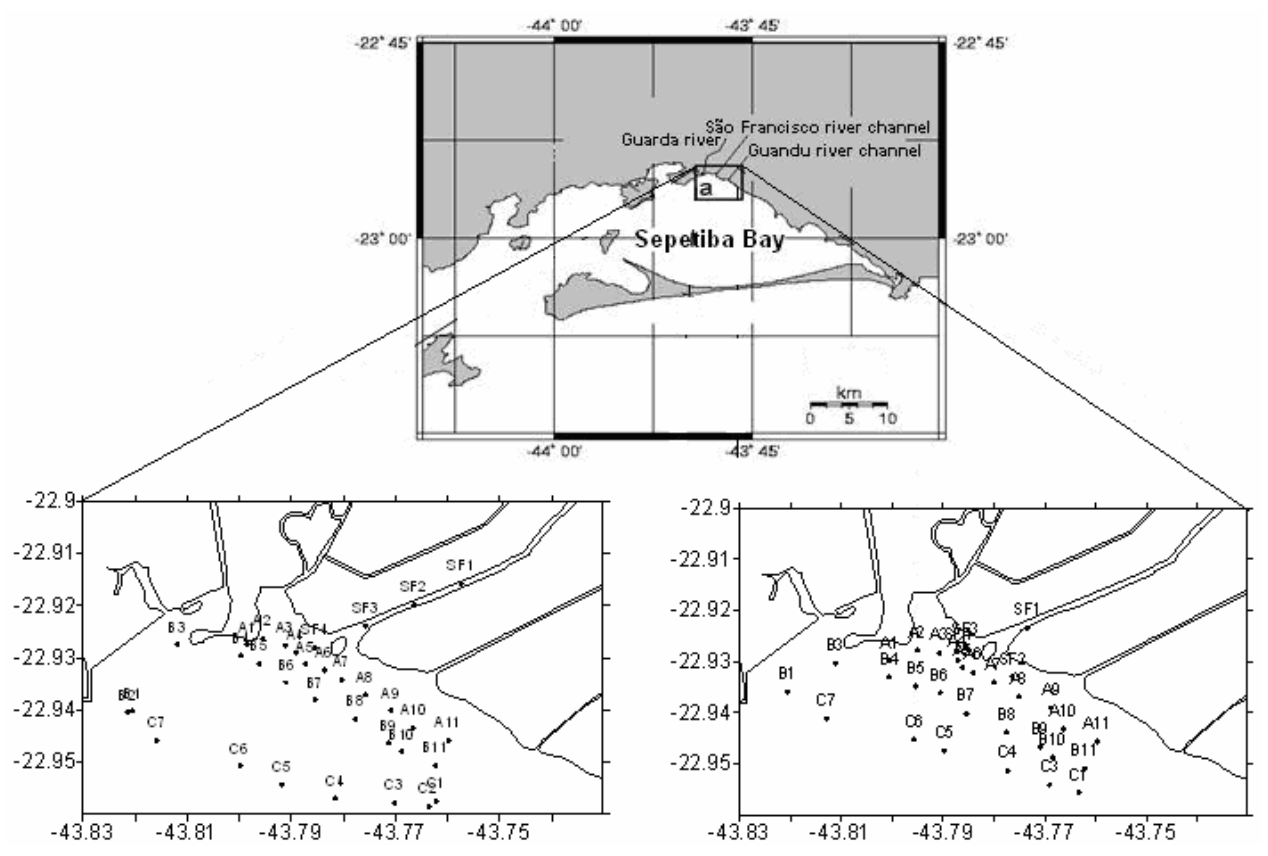

Figure 1 - Location of Sepetiba Bay and the study area (a), with the surface water sampling stations of the higher water discharge event in January (left panel) and lower discharge event in June (right panel) 2003, respectively. Note: stations denominated as SF 1 to 4 are located within the São Francisco river channel, the major fresh water source to Sepetiba Bay. The adjacent shallow Guandú River channel is a minor fresh water source contaminated by domestic effluents. Transects set parallel to shore differed between the campaigns in accordance to the extension of the outer limits of the plumes. 


\section{MATERIAL AND METHODS}

\section{The Study Area}

Sepetiba bay (Fig. 1) extends between Latitudes $22^{\circ} 54^{\prime}$ and $23^{\circ} 04^{\prime} \mathrm{S}$ and Longitudes $43^{\circ} 33^{\prime}$ and $44^{\circ} 02^{\prime}$ W, State of Rio de Janeiro, SE-Brazil. It is a partially mixed and microtidal estuarine-lagoon, with a mean surface area of $427 \mathrm{Km}^{2}$, a volume of $2.56 \times 10^{9} \mathrm{~m}^{3}$ and a mean depth of $6 \mathrm{~m}$. Its drainage basin has an area of $2.711 \mathrm{Km}^{2}$ and sustains manifold human activities, including petrochemical industries, urbanization and engineering works along its mid- to lower river courses (Lacerda et al., 2001). The basins population amounts to 1400000 inhabitants (ANA, 2002). The main tributary of Sepetiba Bay is the Guandú River, which discharges $6.5 \times 10^{6} \mathrm{~m}^{3}$ year ${ }^{1}$ or $86 \%$ of the total freshwater flow to the bay (Molisani et al., 2006). The major fraction of the water originates from the Paraíba do Sul river, being diverted to the middle reaches of the Guandú River and, henceforth, for usage by the Municipality of Rio de Janeiro. About 50 to $80 \mathrm{~m}^{3} \mathrm{~s}^{-1}$ reaches the coastal plain, where it is delivered into the bay via the two adjacent lain artificial São Francisco and Guandu river channels (Fig. 1). The former corresponds to the main point source of freshwater and also various contaminants of the bay, whereas the latter is a minor secondary freshwater source, albeit highly affected by domestic effluents (SEMADS, 2001).The climate of the basin is tropical humid, Köppen type Awa, with a mean precipitation of $1400 \mathrm{~mm}$ year $^{-1}$ and evaporation of $960 \mathrm{~mm} \mathrm{year}^{-1}$, and is characterized by a well defined wet season during austral summer (December to March) and a dry season in austral winter (June to August) (SEMADS, 2001). Spring tides attain up to $1.3 \mathrm{~m}$ (www.dhn.gov.br).

\section{METHODOLOGY}

The study involved two sampling campaigns in the year 2003, one during the "wet" period in January and the other during the "dry" period in June. The former was characterized by a monthly precipitation of $256 \mathrm{~mm}$, a freshwater discharge of the Sao Francisco Channel at about $90 \mathrm{~m}^{3} \mathrm{~s}^{-1}$ and flood tide conditions, whereas the latter by a precipitation of $10 \mathrm{~mm}$, a discharge of about $50 \mathrm{~m}^{3}$ $\mathrm{s}^{-1}$ and low tide conditions. The campaigns were performed with a skiff, comprehending In Situ measurements of physical-chemical parameters and the collection of surface water samples at stations along three transects (A, B and C, Fig.1) set parallel to shore, as well as, within the Sao Francisco Channel (Stations SF, Fig. 1). Station positions were fixed by a GPS, type Garmin II.

Salinity and temperature were measured In Situ with a thermo-salinometer Type MC 5, Electronic Switchgear, London, and water transparency with a Secchi Disc. Water samples were collected with a Hydrobios-Kiel type hydrocast and stored in 0.1 N HCL pre-washed Nalgene bottles over ice in the dark, until further processing in the laboratory, at a maximum of 5 hours after collection. Particulates were retained on Whatmann GF/F filters, and analyzed for their content of suspended particulate matter (SPM) and Chlorophyll a (Chl. a), in accordance to Strickland and Parsons (1972).

Chlorophyll a concentrations were calculated as described by Jeffrey and Humphrey (1975). Filtrates were analyzed for the dissolved inorganic nutrients ammonia $\left(\mathrm{NH}_{4}{ }^{+}-\mathrm{N}\right)$, nitrite $\left(\mathrm{NO}_{2}^{-}-\mathrm{N}\right)$, nitrate $\left(\mathrm{NO}_{3}{ }^{-} \mathrm{-}\right)$, orthophosphate $\left(\mathrm{PO}_{4}{ }^{3-}-\mathrm{P}\right)$ and silicate $\left(\mathrm{H}_{4} \mathrm{SiO}_{4}-\mathrm{Si}\right.$ or DSi), as in Grasshoff et al. (1983). All readings were performed with a spectrophotometer UV-Vis, HITACHI Type 100.

The horizontal distribution of the constituents were plotted with the SURFER 7.0 program and the analyses on the behavior of the constituents along the estuarine gradient, were performed by the simple "mixing curve" method, by plotting the concentration of the constituent against the conservative tracer salinity (BOYLE et al., 1974).

\section{RESULTS AND DISCUSSION}

\section{Physical and chemical boundary conditions of the plumes}

The river plumes of the "wet" and "dry" events (January and June, respectively) dispersed over shallow waters towards the inner portion of Sepetiba bay and were primarily generated by the input of fresh water from the Sao Francisco river channel. However, they differed with respect to their dispersal patterns, extension and magnitude of physical-chemical estuarine gradients. This was brought about by the distinct physical and chemical boundary conditions of the fresh and marine end-member sources of the events (Tab. 1). The plume in January was driven by high river discharge at flood tide conditions and in June, by a 
lower fresh water discharge at low tide conditions. River water concentrations of suspended particulate matter (SPM) and ammonia $\left(\mathrm{NH}_{4}{ }^{+}-\mathrm{N}\right)$ were more than two-fold higher during the January event. The $\mathrm{NH}_{4}{ }^{+}-\mathrm{N}$ levels indicated the presence of contamination by domestic effluents (SEMADS, 2001) and/or enhanced degradation of organic matter within the river channel. Some other anthropogenic impact, such as fertilizer usage, and/or nitrification in the river channel, might have been responsible for the relatively similar and high nitrate $\left(\mathrm{NO}_{3}{ }^{-}-\mathrm{N}\right)$ concentrations and also elevated $\mathrm{N}: \mathrm{P}$ ratios $(\approx 50$ to $100: 1)$ encountered during both events. Contrary to expectations, riverine dissolved silica (DSi) was slightly lower during the January event than the June event. Other small and moderately impacted rivers of the eastern coast of the State of Rio de Janeiro, generally exhibit lower DIN, but similar DIP and DSi levels as of this study (Knoppers et al., 1999a).

\section{Physical conditions of the plumes}

The spatial distribution of salinity (Fig.2) clearly demonstrated that the plume of the "wet" January event was larger than during the "dry" June event. The former dispersed oblique to shore in a SSE direction, extending beyond the $5 \mathrm{~m}$ isobath and up to about $3 \mathrm{~km}$ from shore. A study by FEEMA (2000) suggested, that the Sao Francisco river channel plume extends most during high discharge and negligible alongshore currents. The plume of the "wet" event also lacked a clear salinity front and was slightly more affected by the fresh water input from the secondary Guandú river channel source. The "dry" event plume proliferated 1,5 km alongshore within the premises of the $2 \mathrm{~m}$ isobath and harbored a clear salinity front close to shore.

Salinity intrusion into the São Francisco river channel was minor. The oligohaline portion $(S=0$ to 5) of the estuarine mixing zone was restricted to a small stretch inwards and outwards of the Sao Francisco river channel mouth (Fig. 2). Estuarineplume systems of medium to large rivers also demonstrate a similar setting of the oligohaline portion of the mixing zone around the river mouth during high water discharge conditions (Wright and Nittrouer, 1995; Knoppers et al., 2005). This suggests that similar trends between small and large-scale plumes might persist.

The impact of temperature upon the density displacement of the plumes was, as expected, minor in comparison to salinity, but revealed some degree of spatial and temporal variability. Temperatures in January ranged from $25.9{ }^{\circ} \mathrm{C}$ to $30{ }^{\circ} \mathrm{C}$ and in June from $23.8^{\circ} \mathrm{C}$ to $24.8{ }^{\circ} \mathrm{C}$ (Tab. 1 ). Highest temperatures were encountered close to the mouth of the Guandú river channel, which may be attributed to a combination of features enhancing heat storage, such as the shallowness of the area, the minor flow and contamination by domestic effluents of the river channel (SEMADS, 2001).

Table 1 - Physical and chemical boundary conditions of the fresh and marine end-member sources during the "wet" (January) and "dry" (June) events of the study. Twin values in the first column correspond to measurements performed during two consecutive sampling days in the Sao Francisco River Channel. Qr = river discharge.

\begin{tabular}{lcccc}
\hline \multirow{2}{*}{ Parameters } & \multicolumn{2}{c}{ Wet Period } & \multicolumn{2}{c}{ Dry Period } \\
\cline { 2 - 5 } & \multicolumn{1}{c}{ River } & Marine & River & Marine \\
\hline $\mathrm{Q}_{\mathrm{r}}\left(\mathrm{m}^{3} / \mathrm{s}\right)$ & 90 & - & 50 & - \\
$\mathrm{Tide}$ & - & flood & - & $\mathrm{ebb}$ \\
$\mathrm{T}\left({ }^{\circ} \mathrm{C}\right)$ & 30 & 25.9 & 24.8 & 23.8 \\
$\mathrm{~S}$ & 0 & 32.2 & 0.5 & 31.7 \\
$\mathrm{SPM}(\mathrm{mg} / \mathrm{l})$ & $32.2 / 27.83$ & 11.35 & 6.36 & 7.32 \\
$\mathrm{DSi}(\mu \mathrm{M})$ & $42.6 / 22.10$ & 9.05 & 55.12 & 15.96 \\
$\mathrm{NO}_{3}^{-}-\mathrm{N}(\mu \mathrm{M})$ & $62.6 / 29.47$ & 0.23 & 67.11 & 5.11 \\
$\mathrm{NO}_{2}^{-}-\mathrm{N}(\mu \mathrm{M})$ & $0.62 / 0.98$ & 0.35 & 1.21 & 0.19 \\
$\mathrm{NH}_{4}{ }^{+}-\mathrm{N}(\mu \mathrm{M})$ & 11.54 & 1.37 & 3.24 & 1.29 \\
$\mathrm{DIN}^{3-}(\mu \mathrm{M})$ & $65.0 / 41.99$ & 1.95 & 71.56 & 1.59 \\
$\mathrm{PO}_{4}{ }^{--}-\mathrm{P}(\mu \mathrm{M})$ & $1.27 / 0.64$ & 0.36 & 0.70 & 0.05 \\
$\mathrm{DIN}: \mathrm{P}$ & $51.2 / 65.60$ & 5.41 & 102.23 & 31.8 \\
$\mathrm{DSi}: \mathrm{DIN}$ & $1.76 / 0.53$ & 4.64 & 0.77 & 2.42 \\
\hline
\end{tabular}


The small-sized plume of this study behaved as a typical turbidity plume of larger river systems. SPM concentrations in January (7.0 to $53.3 \mathrm{mg} \mathrm{L}^{-}$ ${ }^{1}$ ) were two-fold higher than in June (3.1 to 21.8 $\mathrm{mg} \mathrm{L}^{-1}$ ), exhibited considerable patchiness allover, and higher levels off the river mouth (Fig. 3) in comparison to the river sources (Table 1). This is a common pattern encountered for most estuarineplume systems harboring shallow waters off their river mouth, subject to bottom re-suspension processes of SPM by wave and tidal energy and bottom shear effects from river flow (Dyer, 1997; Officer, 1976; Wainright, 1990). Similar SPM concentrations and dispersal patterns have also been found for the larger coastal-shelf plumes of the Paraíba do Sul and São Francisco rivers, East coast of Brazil, subject to a high wave energy regime (Carneiro, 1998; Knoppers et al., 1999b and 2005). In the present case, however, conditions were more likely generated by tidal pumping, as winds and waves were negligible.

\section{Nutrients and trophic conditions of the plumes}

The January event plume was more nutrient rich than the June event plume, in accordance to the impact of material loads from the rivers. The former event also demonstrated a larger degree of nutrient patchiness than the latter, which, apart from river loading, may also be attributed to the differences between the extension of the plumes and the influence of changes in bottom topography. DSi for example, exhibited its greatest concentrations in January (range 1.77 to 114.40 $\mu$ mol L ${ }^{-1}$ ) within the mid-plume section, whereas in June the highest levels (range 0.62 to 93.83 $\mu \mathrm{mol} \mathrm{L}{ }^{-1}$ ) were restricted to the river mouth. The mid-plume DSi levels exceeded two-fold in comparison to those of the river source (Tab.1). In contrast, extreme impoverished DSi concentrations were detected at the outer premises of the plume and bay waters during both occasions, suggesting that consumption by phytoplankton (i.e. diatoms) must have been taking place. A similar dispersal pattern and behavior to $\mathrm{DSi}$, was also detected for orthophosphate $\left(\mathrm{HPO}_{4}{ }^{-2}-\mathrm{P}\right)$, characterized by higher concentrations in January (range 0.90 to $1.77 \mu \mathrm{mol} \mathrm{L}^{-1}$ ) than in June (range 0.05 to 0.70 $\mu \mathrm{mol} \mathrm{L} \mathrm{L}^{-1}$ ).

In contrast the nitrogenous nutrients differed markedly in their dispersal patterns. Nitrate plus nitrite $\left(\mathrm{NO}_{3}^{-}-\mathrm{N}+\mathrm{NO}_{2}^{-}-\mathrm{N}\right)$ dispersed in a rather conservative and similar fashion during January (range 0.53 to $63.66 \mu \mathrm{mol} \mathrm{L}{ }^{-1}$ ) and June (range 2.21 to $69.62 \mu \mathrm{mol} \mathrm{L}^{-1}$ ), with plume concentrations being imminently controlled by the fresh water source and dilution towards the bays waters. On the other hand, ammonium harbored some peculiarities of its own (Fig. 4). Increments were detected within the mid-plume section attaining up to $15.1 \mu \mathrm{mol} \mathrm{L}{ }^{-1}$ in January and $7,5 \mu \mathrm{mol} \mathrm{L}-1$ in June, but extremely high concentrations of up to $165.21 \mu \mathrm{mol} \mathrm{L}{ }^{-1}$ (January) and $189.92 \mu \mathrm{mol} \mathrm{L}^{-1}$ (June) were detected off the Guandú channel mouth, corroborating the impact of domestic effluents by this source to the bay.

The N:P ratios (Fig. 5) diminished from the river to the marine end-member source, but were clearly affected by the extreme ammonia concentrations introduced by the Guandú channel. They were by a factor of two lower in January than in June, mainly due to the concomitant increase of ammonia and the impoverishment of orthophosphate during the June event. Nevertheless, N:P ratios throughout the plumes and, to some extent also in the bays waters, were well beyond the Redfield N:P ratio of 16:1, considered as the ideal nutrient mix for the demand by phytoplankton primary production (Redfield, 1958). As corroborated by the high N:P ratios depicted in Table 1, the river source with its high nitrate concentrations and also contamination by ammonia, imposed phosphorous limited conditions upon primary production of the bay.

When comparing the dispersal patterns of SPM (Fig. 3), the $\mathrm{N}: \mathrm{P}$ ratio (Fig. 4) and the phytoplankton biomass indicator chlorophyll $a$ (Chl. $a$; Fig. 5), a spatial de-coupling of the parameters becomes evident. Chlorophyll $a$ concentrations increased at the outer premises of the plume, suggesting that the short residence times and light limitation due to turbidity of the inner to mid-plume waters, hampered primary production nearshore, particularly during the "wet" January occasion. In accordance to the trophic state indexes of Lambou et al. (1983), Chlorophyll $a$ at the outer plume indicated mesotrophic conditions and the nutrient assemblages at the fresh water sources hypertrophic conditions. 

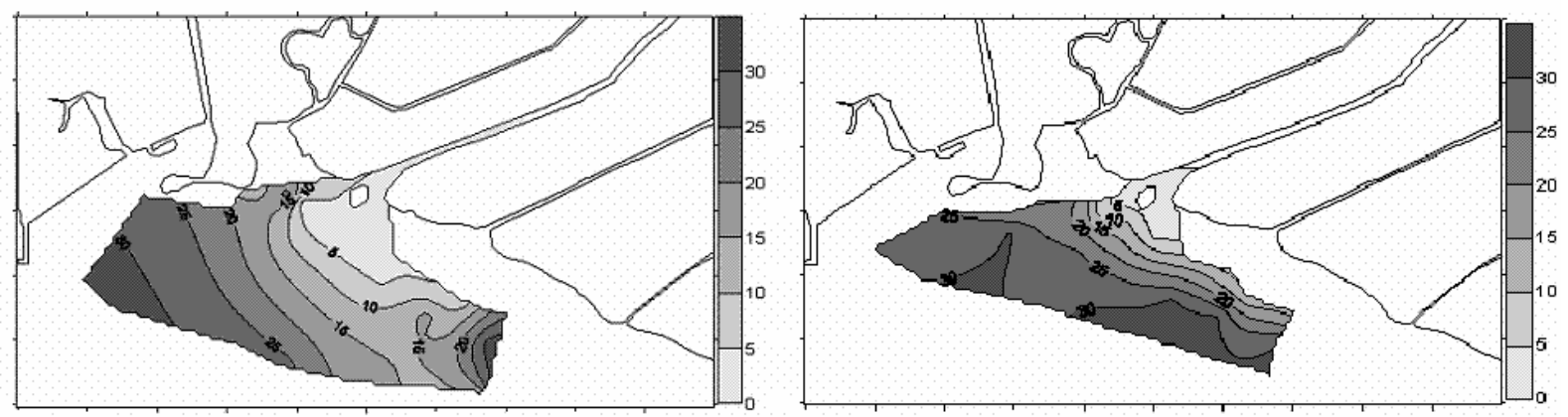

Figure 2 - Horizontal distribution of salinity in January (a) and in June (b) 2003 of the São Francisco river plume, Sepetiba bay.
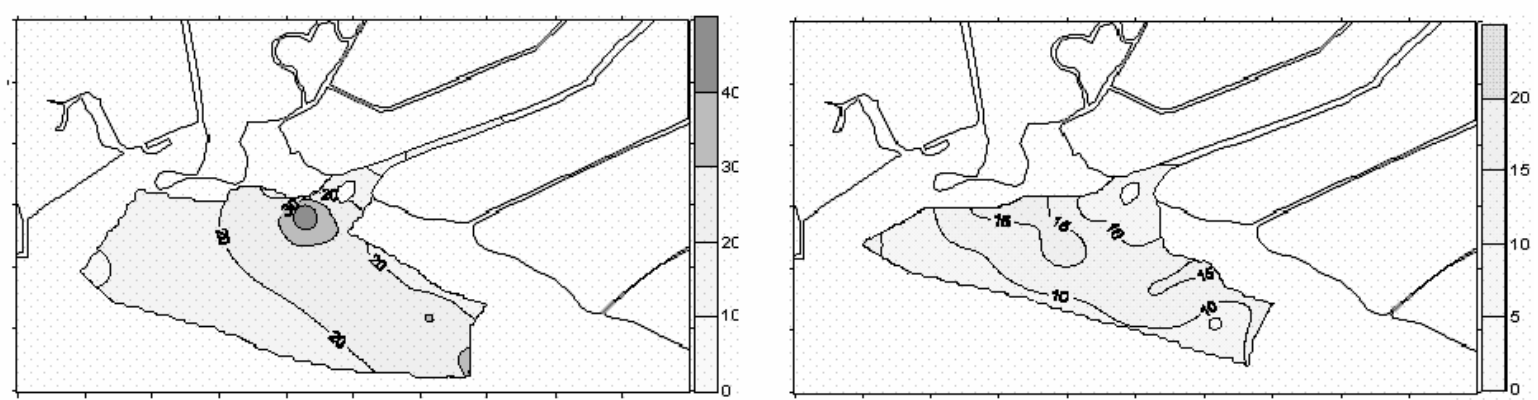

Figure 3 - Horizontal distribution of suspended particulate matter (SPM) in January (a) and in June (b) 2003 of the São Francisco river plume, Sepetiba bay.
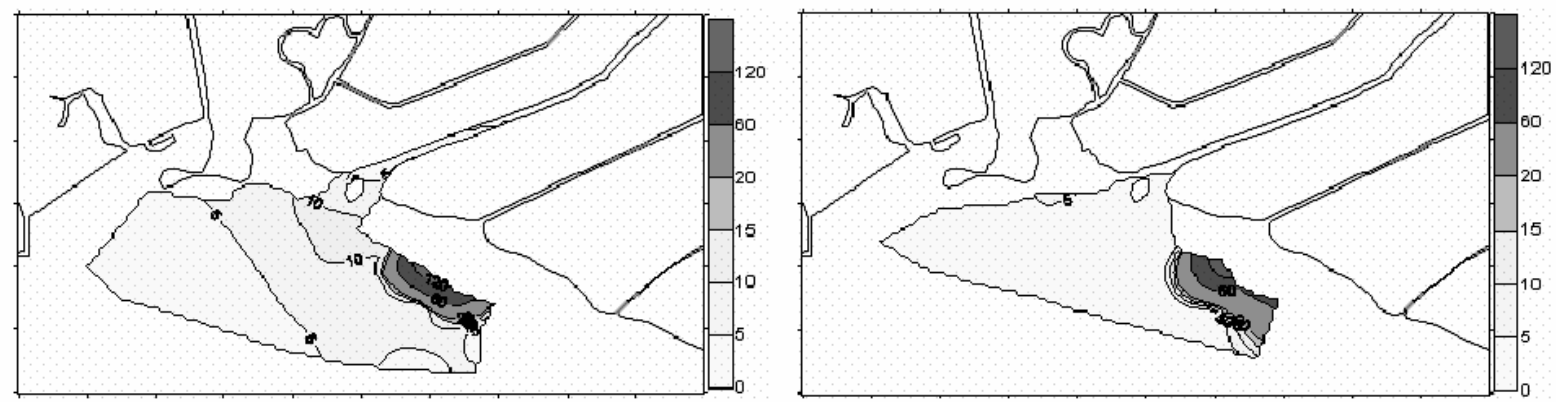

Figure 4 - Horizontal distribution of ammonia $\left(\mathrm{NH}_{4}{ }^{+}-\mathrm{N}\right)$ in January (a) and in June (b) 2003 of the São Francisco river plume, Sepetiba bay.
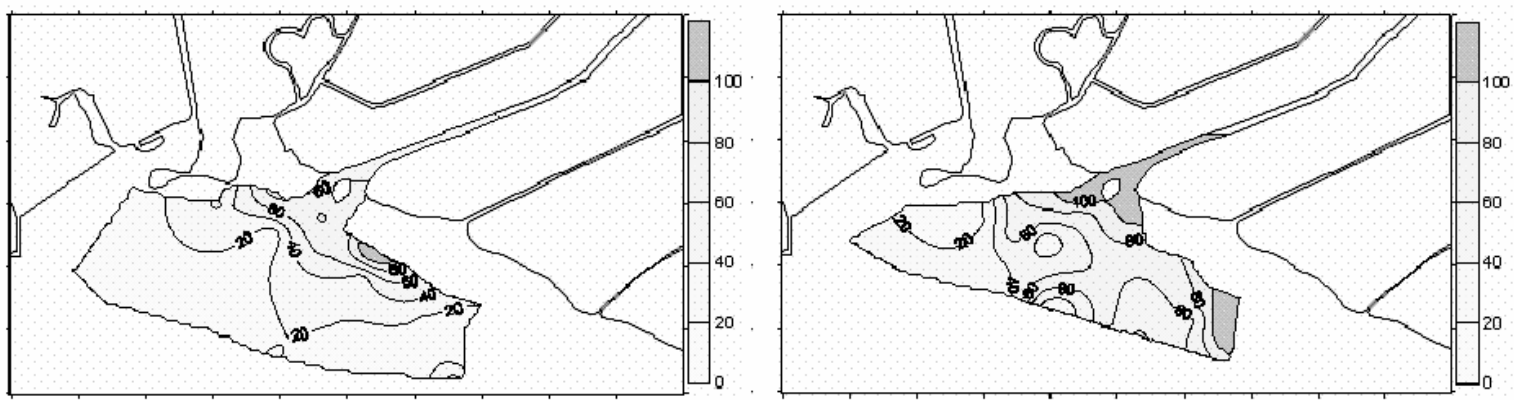

Figure 5 - Horizontal distribution of the N:P ratio in January (a) and in June (b) of the São Francisco/Guandú river plume. 

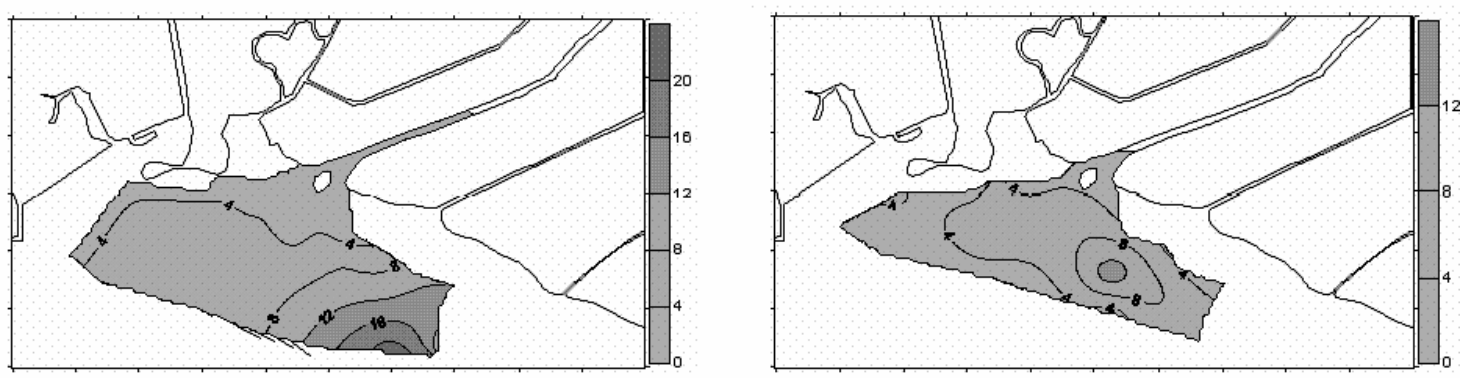

Figure 6 - Horizontal distribution of Chlorophyll $a$ in January (a) and in June (b) 2003 of the São Francisco river plume.

\section{Sources and sinks along the estuarine mixing zone}

The horizontal dispersal patterns described, revealed a great deal of patchiness of the physical and chemical constituents throughout the plumes. However, to better illustrate the behavior and dynamics of the constituents and define the impact of sediment-water interactions during plume dispersal, the traditional and simple "mixing curve" approach is adopted (Edwards and Liss, 1973; Boyle, 1974; Burton and Liss, 1976). It involves the comparison of material concentrations between non-reactive (i.e. salt) and reactive inorganic and organic constituents, to elucidate the degree to which the estuarine mixing zone serves as a source or a sink of materials (e.g. nonconservative behavior) or whether materials are transported without reactions (e.g. conservative behavior), being merely diluted in proportion to mixing.

It must be borne in mind, that the simple mixing curve approach has generally been applied to estuarine mixing zones confined to within estuaries along their longitudinal axis, corresponding as such to 2-D conditions. The restrictions imposed to its application to 3-D dispersal systems with estuarine mixing zones set beyond the river mouth, as is the case of this study, has been discussed by Cifuentes et al. (1990). Under these conditions, the approach may become semi-quantitative only, as other processes such as lateral advection of water and associated materials affect estuarine mixing.

Figure 7 presents the composite plots of salinity against the concentrations of the studied constituents. The composite plots corroborate the greater deal of material variability imposed by the 3-D dispersal of the plume and also the impact by multiple material sources. In general, variability during estuarine mixing was greater during the
January event in comparison to the June event. The constituents SPM, DIP, DSi and ammonia, behaved in a non-conservative fashion, particularly along the mesohaline portion $(S=5$ $20)$ of the mixing zone. This should corroborate that the bottom served as a material source to the plume waters. Resuspension processes by physical forcing not only enhanced input of SPM, but also dissolved inorganic nutrients contained in pore waters of the surface sediments. These mechanisms, including their relevance for the sustenance of primary production, have been widely discussed for other tropical estuarinelagoon systems, including those of the south- east coast of Brazil (Knoppers et al. 1999c).

The mixing curves of Figure 7 also lacked the typical loss in the behavior of DIP and ammonia along the oligohaline portion of the estuarine mixing zone, where most particle-water interactions such as adsorption and coprecipitation processes occur (Burton and Liss, 1976; Turner and Millward, 2002). These might be operating at the inner portion of the Sao Francisco river channel mouth, but the extreme short distance of this salinity gradient likely masks these effects. In addition, the mixing curves also served well to detect the drastic lateral input of ammonia by the Guandú river channel, but at the same time reflected that the usage of the mixing curve for mass balance assertions in this study was constrained by the multiple material sources. Similar conditions have also been found for the Paranaguá estuary, affected by lateral inputs of domestic discharge and ammonia from the bottom, but the approach rendered more consistent results as the system corresponded to a larger estuary with greater depths, devoid of intense SPM from the bottom along its central channel (Knoppers et al., 1984). 

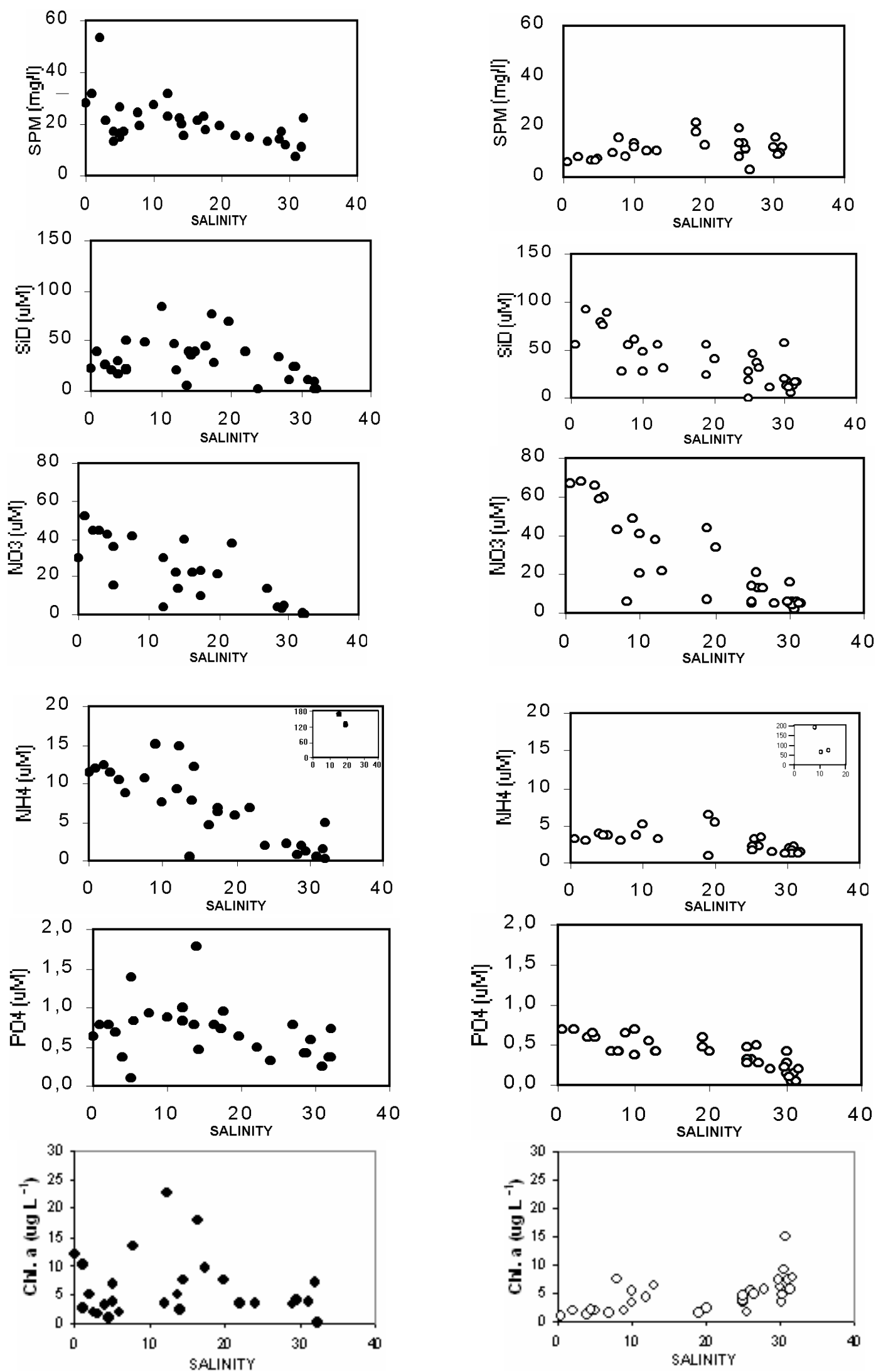

Figure 7 - Composite plots of suspended particulate matter (SPM) and dissolved inorganic nutrients against salinity of the São Francisco/Guandú river plume, Sepetiba Bay, for the surveys of January 2003 (filled circles) and June 2003 (open circles). 
Figure 7 corroborates the de-coupling in the behavior of SPM and Chlorophyll $a$ during plume dispersal, but also a direct coupling between the estuarine mixing and the turbidity zones. The latter is contrary to the conditions generally observed for medium to large-sized plume systems which proliferate over coastal-shelf waters (Wright and Nittrouer, 1995; Berlinsky et al. 2005; Knoppers et al., 2005; Smoak et al., 2005). The coupling between both zones is considered as the intrinsic feature of the small-scale plume studied in Sepetiba Bay.

\section{CONCLUSION}

The extension, form and material concentrations of small-sized plumes generated by the Sao Francisco- Guandú river channels, differed considerably between the high and low discharge events. Under the former condition, the plume exhibited a larger potential of fertilization to the central inner portion of Sepetiba bay than the latter, which enhanced material retainance nearshore. They were affected by multiple material sources, including lateral river inputs and the bottom sediments. The shallow depths enhanced a direct coupling of sediment-water interactions. Tidal pumping and likely also bottom shear stress from river flow, were responsible for the resuspension of SPM and nutrient release from the surface sediments. The plumes exhibited a clear de-coupling between the turbidity and chlorophyll zones, but a direct coupling between the turbidity and estuarine mixing zone, not observed in medium to large-scale plumes of coastal-shelf waters.

\section{ACKNOWLEDGEMENTS}

This work was supported by the FAPERJ/CNPJ through Project PRONEX number E26/171.175/2003 and Instituto do Millenium CNPq project Nr. 420050/2005-1. B. Knoppers is a CNPq Fellow (Proc. Nr. 300772/2004-1). We thank John Maddock, Renato Carreira, Sambasiva Patchineelan, Emmanoel Silva, Bruno Turcq and Edison Bidone for useful suggestions. We also thank the different laboratories of Geochemistry Department of the University Federal Fluminense for cooperation in analyses.

\section{RESUMO}

A extensão, forma e as concentrações da matéria das plumas de pequena escala geradas pelos canais dos rios São Francisco e Guandu, se diferenciaram consideravelmente entre os eventos de alta e baixa descarga. A pluma durante o evento de alta descarga apresentou maior potencial de fertilização da parte central interna da Baía de Sepetiba, enquanto a pluma de baixa descarga fluvial reteve materiais próximo da costa em área rasa. As plumas foram impactadas por múltiplas fontes de materiais, incluindo o aporte lateral fluvial e os sedimentos do fundo. A baixa profundidade da área foi responsável pelo acoplamento nítido da água e do sedimento. O bombeamento da maré com, provavelmente, o atrito no fundo gerado pelo fluxo fluvial, foram responsáveis pela ressuspensão de matéria em suspensão e a liberação de nutrientes dos sedimentos superficiais. As plumas apresentaram um desacoplamento nítido entre as zonas de turbidez e a clorofila, e um acoplamento entre as zonas de turbidez e de mistura estuarina, geralmente não observado em plumas de médio a grande porte que se proliferam na costa $\mathrm{e}$ plataforma continental.

\section{REFERENCES}

ANA - Agência Nacional de Águas (2002), Bacias hidrográficas do Atlântico Sul - Trecho leste. Série Sistema Nacional de Informações sobre Recursos Hídricos CD-ROM n:4.

Boyle, E.; Collier, R.; Dengler, A. T.; Edmond, J. M.; Ng, A.C. and Stallard, R.F. (1974), On the chemical mass-balance in estuaries. Geochimica et Cosmochimica Acta, 38, 1719-1728.

Berlinsky, N.; Bogatova, Y. and Garkavaya, G. (2005), Estuary of the Danube. In-Estuaries-Pollution The Handbook of Environemental Chemistry Vol. 5H., ed. P. J. Wangersky. Springer Verlag, Berlin. pp. 233264.

Burton, J. D. and Liss, P. S. (1976), Estuarine chemistry. Academic Press, London

Carneiro, M. E. (1998), Origem, transporte e destino de matéria biogênica e hidrocarbonetos no estuário do Rio Paraíba do Sul. PhD Thesis, Universidade Federal Fluminense, Niterói, Brasil

Cifuentes, L. A.; Schemel, L. E. and Sharp, J. H. (1990), Modelling C, N and P fluxes in estuaries. Estuarine, Coastal and Shelf Science, 30, 411-423 
Day Jr., J. W.; Hall, C. A. S.; Kemp, W. M. and YañezArancibia, A. (1989), Estuarine ecology. John Wiley, New York

Duxbury, A. C. (1972), Variability of salinity and nutrients off the Columbia River Mouth. In-Columbia river estuary and adjacent ocean waters, eds. A. T. Pruter and D.L Alverson. University of Washington Press, Seattle

Dyer, K. R. (1997), Estuaries: a physical introduction. John Wiley, London

Edwards, A. M. C. and Liss, P. S. (1973), Evidence for buffering of dissolved silicon in freshwaters. Nature, 243, 341-342

FEEMA. (2000), Avaliação da qualidade da água da bacia da Baía de Sepetiba: outubro 95/ julho 98. Rio de Janeiro: FEEMA, CD-ROM. Relatório do Projeto de Cooperação Técnica Brasil - Alemanha.

Garvine, R. W. (1987), Estuary plumes and fronts in shelf waters: a layer model. Journal of Physical Oceanography, 17, 1877-1896

Garvine R. W. (1995), A dynamical system for classifying buoyant coastal discharges. Continental Shelf Research, 15, 1585-1600

Grasshoff, K.; Kremling, K. and Ehrhardt, M. (1983), Methods of seawater analysis. 2nd ed. Verlag Chemie, Weinheim

Jeffrey, S. W. and Humphrey, G. F. (1975), New spectrophotometric equations for determining chlorophylls a, b, c1 + c2 in higher plants, algae and natural phytoplankton. Biochem. Physiol. Pflanzen. Bd., 167, 191-194

Knoppers, B.; Brandini, F. and Thamm, C. (1984), Ecological studies in Paranaguá Bay.II: Some physical and chemical characteristics. Nerítica, 2, 136

Knoppers, B.; Carmouze, J.P. and Moreira-Turcq, P.F. (1999a), Nutrients, metabolism and eutrophication of lagoons along the East Fluminense coast, State of Rio de Janeiro, Brazil. In-Environmental Geochemistry of Coastal Lagoon Systems of Rio de Janeiro, Brazil. eds B. Knoppers, E.D. Bidone and J.J. Abrao. Série Geoquímica Ambiental 6. Programa Geoquímica Ambiental UFF/FINEP, Niterói/Rio de Janeiro, pp. 123-154

Knoppers, B.; Ekau, W.; Figeuiredo, A.G. (1999b), The coast and shelf of east and northeast Brazil and material transport. Geo-Marine Letters, 19, 171-178

Knoppers, B. and Kjerfve, B. (1999c). Coastal laogoons of southeastern Brazil: Physical and biogeochemical characteristics. In-Estuaries of South America. eds. G. Perillo; C. Piccolo and P. Quivira. Springer Verlag, Berlin

Knoppers, B.; Medeiros, P.R.P.; Souza, W.F.L. de and Jennerjanh, T. (2005), The Sao Francisco Estuary. InEstuaries-Pollution.TheHandbook of Environmental Chemistry Vol. 5H.. ed. P. J. Wangersky. Springer Verlag, Berlin, pp. 51-70
Lacerda, L.D.; Marins, R.V.; Barcellos, C. and Knoppers, B.A. (2001), River basin activities, impact and management of anthropogenic trace metal and sediment fluxes to Sepetiba Nay, Southeastern Brazil. In-Science and Integrated Coastal Management . Dahlem Workshop Report 85. ed. B.v. Bodungen and R.K. Turner. Dahlem University Press, Berlin pp. 203-212

Lambou, V. W.; Taylor, W. D.; Hern, S. C. and Williams L. R. (1983), Comparisons of trophic state measurements. Water Research, 17, 1619-1626

Molisani,, M. M.; Kjerfve, B.; Silva, A. P. and Lacerda, L. D. (2006), Water discharge and sediment load to Seperiba Bay from an anthropogenically-alterd drainage basin, SE Brazil. Journal of Hydrology, 331, 425-433

Officer, C. B. (1976), Physical oceanography of estuaries (and Associated Coastal Waters). John Willey, New York

Redfield, A. C. (1958), The biological control of chemical factors in the environment. American Scientist, 46, 205-221

SEMADS. (2001), Bacias Hidrográficas e Recursos Hídricos da Macrorregião Ambiental 2 - Bacia da Baía de Sepetiba. Projeto PLANAGUA SEMADS/GTZ. Cooperação Técnica BrasilAlemanha. Rio de Janeiro

Smith, S. V. and Atkinson, M. J. (1994), .Mass balance of nutrient fluxes in coastal lagoons. In-Coastal Lagoon Processes, ed. B. Kjerfve. Elsevier, Amsterdam

Smoak, J.M.; Krest, J.M. and Swarzenski, P.W. (2005), Geochemistry of the Amazon Estuary. In-EstuariesPollution. The Handbook of Environemental Chemistry Vol. 5H. ed. P. J. Wangersky. Springer Verlag, Berlin

Turner, A. and Millward, G. E. (2002), Suspended particles: their role in estuarine biogeochemical cycles. Estuarine, Coastal and Shelf Science, 55, 857883

Wainright, S. C. (1990), Sediment-to-water fluxes of particulate material and microbes by resuspension and their contribution to the planktonic food web. Mar. Ecol., 62, 271-281

Wright, L.D. (1977), Sediment transport and deposition at river mouths: a synthesis. Bulletin of the American Geological Society, 88, 857-868

Wright, L. D. and Nittrouer, C. A. (1995), Dispersal of river sediments in coastal seas: six contrasting cases, Estuaries, 18, 494-508

Received: February 17, 2006; Revised: May 25, 2007; Accepted: July 24, 2008. 